ENTREPRENEURSHIP AND SUSTAINABILITY ISSUES

ISSN 2345-0282 (online) http://jssidoi.org/jesi/

2020 Volume 7 Number 4 (June)

http://doi.org/10.9770/jesi.2020.7.4(4)

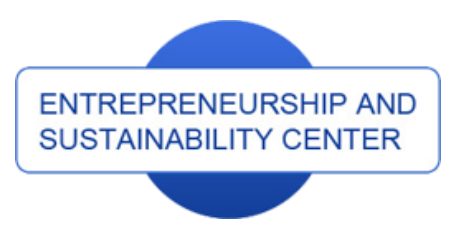

Publisher

http://jssidoi.org/esc/home

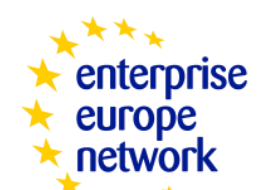

Business Support on Your Doorstep

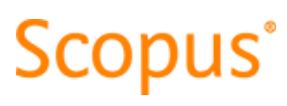

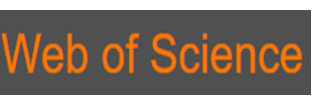

Clarivate
Analytics

\title{
STIMULATION OF ENTREPRENEURS' INNOVATIVE ACTIVITY: EVIDENCE FROM KAZAKHSTAN
}

\author{
Sagyngali Seitzhanov ${ }^{1}$, Nurlan Kurmanov ${ }^{2}$, Mariana Petrova ${ }^{3}$, Ulukbek Aliyev ${ }^{4}$, Nazgul Aidargaliyeva 5 \\ ${ }^{1,2}$ L.N. Gumilyov Eurasian National University, 010008 Satpayev 2 Str., Nur-Sultan, Kazakhstan \\ ${ }^{3}$ St.Cyril and St.Methodius University of Veliko Tarnovo, 5000 T.Tarnovski 2 Str., Veliko Tarnovo, Bulgaria \\ ${ }^{4}$ The Executive Office of the President of the Republic of Kazakhstan, Nur-Sultan, "Akorda", Government House, \\ Kazakhstan \\ ${ }^{5}$ Kazakh Humanitarian Juridical Innovative University, 071400 Mangilikel 11 Str., Semey, Kazakhstan \\ E-mails: ${ }^{1}$ akastana@icloud.com, ${ }^{2}$ kurmanov_na@enu.kz, ${ }^{3}$ m.petrova@ts.uni-vt.bg(Corresponding author), \\ ${ }^{4}$ alivev0901@gmail.com
}

Received 23 November 2019; accepted 20 March 2020; published 30 June 2020

\begin{abstract}
In recent years, Kazakhstan's innovation policy has enjoyed a noticeable rally: ways to support innovation are being actively discussed, a suitable "toolbox" is developing, the susceptibility of decision-makers to the mechanisms for encouraging innovation is increasing. Nevertheless, effective levers of influence on business, in which innovation activity could manifest locally, have not been found yet. Although this does not change the overall economic situation. Following on from the results of a survey of various level business managers and factor analysis performed prior, the authors study the influence of incentive mechanisms on entity activities and their "inquiry" on the public policy content. The authors come to the conclusion that most of the tools to stimulate innovation entrepreneurship in Kazakhstan are currently aimed at successful market players, creating conditions for technological modernization of existing industries, and at improving the level of entrepreneurs' business and technological competencies. According to a study conducted in Kazakhstan, it is necessary to increase the participation of universities, research institutes, local executive and legislative authorities in the development of management mechanisms and the promotion of innovation entrepreneurship.
\end{abstract}

Keywords: innovation management; entrepreneurship; innovation activity; research and development; stimulation; Kazakhstan

Reference to this paper should be made as follows: Seitzhanov, S., Kurmanov, N., Petrova, M., Aliyev, U., Aidargaliyeva, N. 2020. Stimulation of entrepreneurs' innovative activity: evidence from Kazakhstan. Entrepreneurship and Sustainability Issues, 7(4), $2615-2629$. https://doi.org/10.9770/iesi.2020.7.4(4)

JEL Classifications: M13, O31, O32

\section{Introduction}

The state's awareness of the role of innovation in sustainable economic growth has given a certain dynamism to the policy in this area, the support of which has become one of the national priorities. Stimulating measures are being discussed, appropriate tools are being intensively developed. Many of these take no more than a year to be 
tangibly embodied. A certain array of specialized literature has been accumulated, where the need for government intervention in innovation is substantiated, and associated negative practices are analyzed. Experts regularly pay attention to certain examples of the dynamic development of medium-sized businesses, of a substantial increase in innovation expenditures within a number of large companies, of an increase in business interest in the results of research and development (R\&D) and further expanding cooperation with domestic scientific and academic institutions.

Nevertheless, in the midst of these positive processes, qualitative changes in the overall macroeconomic situation of Kazakhstan are still to be observed. Within 2011-2017, only 8.1-9.6\% of entities would implement innovations while the share of innovative products in the total output would remain below $1.6 \%$, and there were no prerequisites for these indicators to grow whatsoever.

The aim of this article is to conduct a study of the impact of incentive mechanisms on the activities of companies and their "request" on the public policy content on the basis of a factor analysis and a sociological survey of Kazakhstan company managers of various levels.

\section{Literature review}

The issue of the state innovation policy effectiveness, and effectiveness of the set of measures adopted has become particularly relevant. According to experts (Howie, 2018), (Odinokova, 2019), (Kireyeva et al., 2018), (Kurmanov et al., 2016), (Labunska et al., 2017), (Kolechkina et al, 2019), (Mikhailov et al, 2018) unrelated state activities may significantly hamper the innovation performance (Naama, 2001; Naama, 2011). In addition, it largely depends on the specifics of various areas and the capabilities of incentive mechanisms. In Kazakhstan, a shortage of empirical study is observed, which is the means of assessing the contribution of various measures to the development of corporate innovations, their relationship with competitiveness and productivity, and researching the models of innovative behavior of firms. In this context, notable publications such as (Onyusheva, 2017), (Smirnova, 2016), (Tumalavičius et al., 2017), (Ivanov et al., 2012), (Caurkubule et al., 2020), (Chehabeddine, Tvaronavičiené, 2020), (Vigliarolo, 2020) are to be singled out. There are even fewer works that would systematically examine the impact of public policy on the behavior of business entities at the micro level (Jumakulov et al., 2019), (Musaripov et al., 2019), (Kurmanov et al., 2019), (Popova et al., 2019), (Pukala \& Petrova, 2019), (Lazarova et al, 2015), (Yankovyi et al., 2019), (Zbierowski, 2017), (Zahars \& Stivrenieks, 2018), (Pachura, 2015), (Lincényi, Čársky, 2020).

Thus, an assessment of the state support tools' contribution that encourage entities to innovate is to be combined with an analysis of the main factors that determine the overall "value" of the corresponding motivation and behavior of innovatively active firms. The effectiveness of innovative activities of entities cannot only be judged on the basis of innovation gross indicators. It is important to determine the sensitivity, orientation of business representatives to them, and behavioral effects. Microeconomic studies of the behavior of entities that are innovative form the basis for such conclusions.

\section{Methods and information sources of research}

As a rule, the assessment of the state policy impact on innovatively active entities, is carried out on the basis of the expert opinion study. It is important to note that the final conclusions are quite sensitive to the selection of experts, and moreover, it happens to be rather rare to ensure the joint activities of various professional group representatives.

The sociological study hypothesis is an assumption of the positive role of incentives and policies in Kazakhstan entities' innovative activities. 
The analysis of state support tools for innovation entrepreneurship is based on a survey of the managers of Kazakhstan's 60 industrial establishments held as part of the Global Challenges Summit 2018 at the XXI Astana Economic Forum in 2018.

The selection of companies included in the survey can be considered balanced on all parameters critical for further analysis. It covers a wide range of businesses of very different levels (both in terms of production and the employee number), age, industry affiliation, etc. The sample structure is shown in table 1.

Table 1. Brief characteristics of the sample

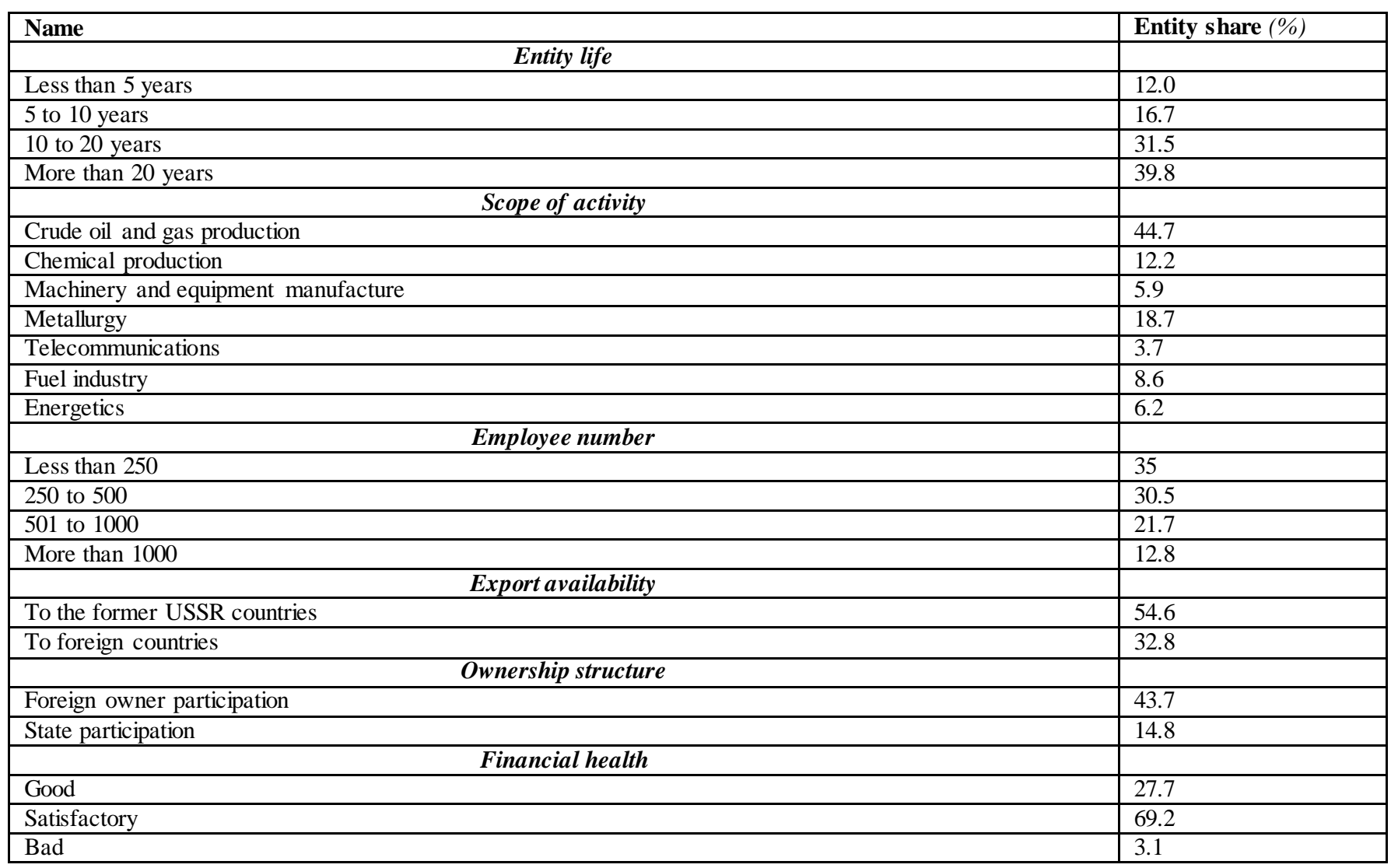

Source: compiled by the authors

A sociological study in this article is aimed at studying incentives for the innovative activities of entities and their "request" for the content of state innovation policy. In this regard, the heads of Kazakhstan companies were asked two main questions:

1) what incentives have the greatest / the least impact on innovation activity?

2) how do state support tools influence the innovation activity of entities?

The survey allows constructing a system of indicators that describe the innovative behavior of entities in the real sector of the economy and the factors that determine it, as well as compare the estimates with the results of other studies. 
The empirical data on the behavioral strategies of Kazakhstan entities obtained during the study makes it possible to clarify the role and importance of the existing state support mechanisms for innovation in business, to assess the "requests" of businesses for the state industrial and innovation policy content to further increase their competitiveness.

Following the analysis of the tools stimulating businesses to innovate during the study. These were classified as follows:

- horizontal incentives which are preferred for horizontally organized economy areas ready to compete with foreign players. These are driven by the example of other players;

- vertical incentives which are peculiar to vertically organized industries. These are due to the transition of major consumers and product suppliers to new technologies;

- technological incentives which are closely related to the offer of technological solutions by experts, scientific and academic institutions;

- coercive incentives which are implemented by the state through the influence of the authorities on the behavior of entities, changing the nature of public procurement, and tightening the requirements of technical regulations.

Preliminary results of the factor analysis of manufacturers' demand for technological innovations and for various tools to stimulate innovation have formed the basis for this article. Factor analysis has revealed factors explaining more than half of the variance of respondents' answers.

\section{Results}

In 2017, in the framework of the scientific theme "Modern mechanisms of innovation management in the development of entrepreneurship in the Republic of Kazakhstan" (Kirdasinova, Kurmanov, 2017), a sociological study was conducted based on a survey of the managers of Kazakhstan's 60 industrial establishments. According to the results of the study, incentives for innovative activities ranked according to the survey of the managers of innovatively active businesses in Kazakhstan (figure 1).

See Figure 1 for the incentives for innovative activities for 2015-2017 ranked according to the survey of the managers of innovatively active businesses in Kazakhstan. 


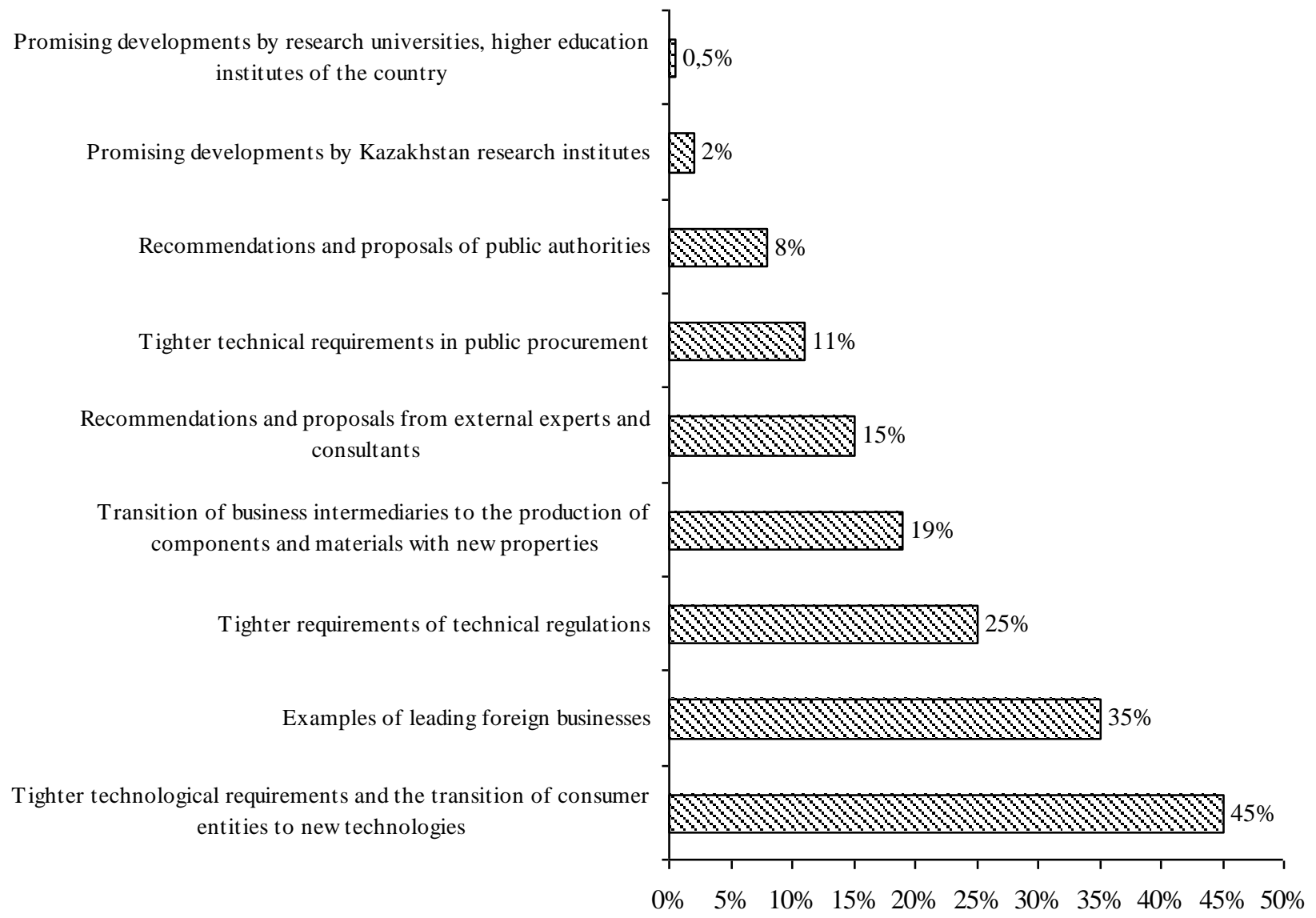

Fig. 1. Incentives for Kazakhstan business innovation activity in 2015-2017

Source: compiled by the authors according to the results of a sociological study

The results of the study in Figure 1 indicate the highest popularity of horizontal and vertical incentives for innovation activity among innovatively active entities in Kazakhstan (45\% and 35\%, respectively).

So far, the state's incentive for the implementation of innovation activities by the entities is manifested in the form of tightening requirements of technical regulations. Only $11 \%$ of domestic innovative businesses note the positive role of public procurement. The contribution of innovation proposal from the Kazakhstan research institutes and research universities seems very limited.

The factor analysis in table 2 has revealed the factors that explain more than half of the variance of respondents' answers. 
Table 2. The results of factor analysis of incentives for innovation at the micro level

\begin{tabular}{|c|c|c|c|c|}
\hline \multirow[b]{2}{*}{ Innovation activity incentive } & \multicolumn{4}{|c|}{ Component factor load } \\
\hline & $\begin{array}{c}\text { Vertical } \\
\text { cooperative }\end{array}$ & $\begin{array}{c}\text { Innovation } \\
\text { proposal }\end{array}$ & $\begin{array}{c}\text { Foreign } \\
\text { practices }\end{array}$ & $\begin{array}{l}\text { Active state } \\
\text { influence }\end{array}$ \\
\hline $\begin{array}{l}\text { Tighter technological requirements and the transition of consumer entities to } \\
\text { new technologies }\end{array}$ & 0.730 & -0.096 & 0.054 & 0.160 \\
\hline Examples of leading foreign businesses & -0.080 & 0.141 & 0.754 & -0.266 \\
\hline Tighter requirements of technical regulations & 0.180 & -0.180 & 0.640 & 0.325 \\
\hline $\begin{array}{l}\text { Transition of business intermediaries to the production of components and } \\
\text { materials with new properties }\end{array}$ & 0.707 & 0.175 & $-0,024$ & -0.188 \\
\hline Tighter technical requirements in public procurement & 0.078 & 0.230 & -0.002 & 0.530 \\
\hline Recommendations and proposals of public authorities & -0.096 & -0.060 & -0.017 & 0.726 \\
\hline Promising developments by Kazakhstan research institutes & 0.009 & 0.740 & -0.069 & 0.130 \\
\hline $\begin{array}{l}\text { Promising developments by research universities, higher education institutes } \\
\text { of the country }\end{array}$ & 0.165 & 0.628 & -0.050 & -0.040 \\
\hline
\end{tabular}

Source: compiled by the authors on the basis of estimates of business managers and calculations by the method of principal components

The revealed factors have coincided practically with the initial assumptions on the main groups of incentives:

- vertical cooperative factor that is associated with the processes of technological updating and the structure of value chains of industrial cooperation. It is important for metallurgy, production of equipment and electric machines, large enterprises.

- proposal of innovation. This factor comes from the external environment of the entity (recommendations and suggestions from consultants and experts, promising developments of domestic research institutes and universities). It stimulates innovation activity in businesses, manufacturers of machinery and electrical equipment, oil and gas sector representatives, players focusing on demand from large businesses and the state.

- foreign practices that is associated with the tightening of technical regulations, often implying the reduction of internal technical standards to the standards of the most developed countries. It is important for large enterprises with the participation of foreign companies and shareholders who are subject to fierce competition with domestic and foreign players, especially in the engineering.

- the active influence of the state. This factor manifests in increasing the technical requirements of public procurement, as well as recommendations and suggestions including informal ones by authorities. It is typical for companies focused on state orders and government sponsored enterprises, primarily in the production of equipment and machinery.

The susceptibility of entities to one or another incentive tool depends on both the individual peculiarities of their activities and objective parameters. Given this circumstance, the relationships of these factors with two main features of the innovation process at the micro level are further considered:

- a positive assessment of the "contribution" to the innovation activity of a competition;

- the constant process of introducing innovations as a mechanism to strengthen the entity's market position.

The first of the features has shown a clear negative relationship with the "active influence of the state." Significantly positive is correlation of this feature with the "innovation proposal" at about $10 \%$. The lack of an explicit linking of the first feature to "foreign practices" can be explained by a direct correlation of this indicator with the intensity of pressure from foreign players - a phenomenon not inherent in optimistic assessments.

The second situation is simpler. It demonstrated a positive dependence only on "foreign practices" and almost complete independence from the other 3 factors. 
In general, we can conclude that measures related to "manual control" and public procurement are primarily sensitive for businesses that are not ready for serious competition and depend largely on the state. In their turn, actions aimed at "pulling up" to the level of leading foreign companies, positively affect Kazakhstan businesses operating in competitive markets and developing according to an innovative model. Thus, in modern conditions, the two most common schemes in Kazakhstan are:

- a horizontal one, based on the experience of foreign companies in conditions of strong competition;

- a vertical one, based on partnership.

At the same time, it should be noted that the model of "innovative supply" bears significant potential in Kazakhstan. It involves technological modernization of businesses in vertically organized sectors and the strengthening of incentives for innovation in their cooperation chains.

Table 3 shows a set of tools that stimulate Kazakhstan entities to carry out innovative activities selected for further analysis.

Table 3. Description of tools for stimulating Kazakhstan entities to implement innovative activities

\begin{tabular}{|c|c|c|}
\hline Tools & Year of application & $\begin{array}{l}\text { Resource volume, } \\
\text { million tenge }\end{array}$ \\
\hline \multicolumn{3}{|l|}{ Tax support } \\
\hline Tax relief when investing into $R \& D$ & 2008 & $\mathrm{n} / \mathrm{a}$ \\
\hline Benefits for special economic zone (SEZ) participants & 2011 & $\mathrm{n} / \mathrm{a}$ \\
\hline \multicolumn{3}{|l|}{ Direct financing } \\
\hline $1 \%$ of the total annual income of subsoil users in $\mathrm{R} \& \mathrm{D}$ & 2017 & $1 \%$ \\
\hline \multicolumn{3}{|l|}{ Financing through development institutions } \\
\hline $\begin{array}{l}\text { Government of Kazakhstan and the World Bank Joint Project "Promoting Productive } \\
\text { Innovation" }\end{array}$ & 2016 & $\$ 110$ million \\
\hline $\begin{array}{l}\text { Innovation funding (for the technological development of industries, the technological } \\
\text { development of existing businesses, the commercialization of technologies) }\end{array}$ & 2015 & 17773,5 \\
\hline $\begin{array}{l}\text { Technology center development with the involvement and co-financing by transnational } \\
\text { corporations }\end{array}$ & 2016 & 1333,9 \\
\hline "ITP" Innovation Cluster and its participants development & 2016 & 1691,6 \\
\hline Nazarbayev University's Business Campus Astana infrastructure development & 2015 & 4219 \\
\hline \multicolumn{3}{|l|}{ Regulation } \\
\hline Technical regulation development, formation of new standards and regulations in the EAEU & $2004 *$ & - \\
\hline \multicolumn{3}{|l|}{ Interaction organization } \\
\hline Promotion and coverage of innovation activity & 2015 & 1136,4 \\
\hline National Innovation Competition holding & 2015 & 281,5 \\
\hline
\end{tabular}

Source: compiled by the authors

Table 3 shows the complex of selected tools stimulating Kazakhstan businesses to carry out innovation activities, which are somewhat "biased" towards innovation infrastructure and financing through development institutions. This is due to current accents in the State program of industrial and innovation performance of the Republic of Kazakhstan for 2015-2019 (SPIID-2) (SPIID for 2015-2019, 2014). They seem to be very "noticeable" in the eyes 
ENTREPRENEURSHIP AND SUSTAINABILITY ISSUES

ISSN 2345-0282 (online) http://jssidoi.org/jesi/ 2020 Volume 7 Number 4 (June)

http://doi.org/10.9770/jesi.2020.7.4(4)

of the expert community, diverse in nature and the expected effects, while they do not have a clear industry focus. This selection, while relatively small in size, clearly reflects the aforementioned trends: "diversification" of support tools and activation of innovation policy.

The heterogeneity of the incentives for the implementation of innovation activities by businesses initially allows to assume a significant difference in the scale of their application. In our opinion, non-selective measures of state support should affect "on average" a wider range of knowledge-based businesses (Koval et al., 2018; Drobnic, 2019).

In general, the interviewed respondents have confirmed the hypothesis about positive contribution of state policy to the business innovation activity (Figure 2).

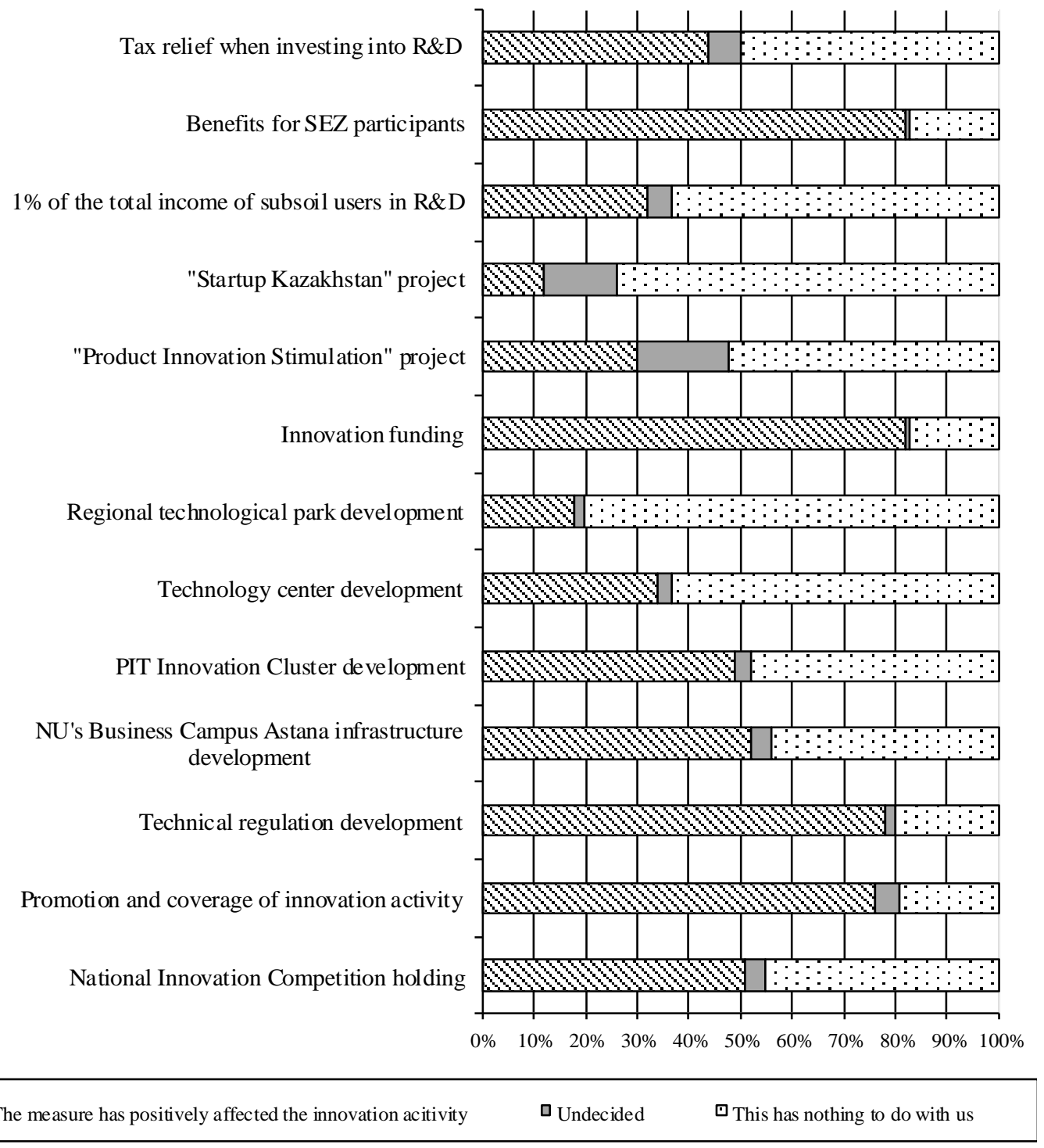

Fig. 2. The impact of state support tools on innovation activities of businesses

Source: Compiled by the authors 
As seen from Figure 2, the focus of tax policy in Kazakhstan on supporting innovative entities is visible to a greater extent on the example of tax relief and preferences provided to payers in the zones with special legal and tax regimes. In the Republic of Kazakhstan, the basic tax rates for the entities engaged in innovation activities in the territories of "ITP" and "Astana-Technopolis" SEZ are reduced by $100 \%$.

The Tax Code of the Republic of Kazakhstan has been introduced with tax incentive measures for the contribution of subsoil users and businesses in $R \& D$. Among those is a direct tax on subsoil users on $R \& D$ in the amount of $1 \%$ of the total annual income and deductions from the tax base of businesses on R\&D in the amount of $50 \%$.

It is important to note that a study of the effectiveness of tax relief aimed at developing innovation and innovation entrepreneurship in Kazakhstan is still to be conducted. In 2011-2012, at the request of the Government of the Republic of Kazakhstan, the UN Economic Commission for Europe conducted a study to assess the innovation performance of Kazakhstan. During this study, the existing tax benefits for knowledge-based businesses have been studied. So, for example the UN Review concludes that the existing system of state support measures for innovation in the country is insufficient and it needs to be expanded in a number of areas. UN experts do not focus on the need to significantly expand the list of tax incentives for innovative businesses. In their opinion, this is due to the fact that Kazakhstan has more powerful factors impeding the transition to the development of an innovative economy than the unfavorable tax regime:

- imperfection of the framework conditions of the NIC;

- insufficient direct funding of science (UNECE, 2012).

The fact that some tax benefits were introduced in Kazakhstan relatively recently is to be considered, and, in our opinion, their effect is yet to manifest itself. Thus, at the moment, assessing the effectiveness of tax incentive measures aimed at stimulating innovation entrepreneurship and innovation performance seems premature.

In our study, a direct tax for subsoil users on research and development in the amount of $1 \%$ of the total annual income was attributed to direct financing of innovative activities of entities. So, in accordance with the new Tax Code of the Republic of Kazakhstan, these funds will be transferred to the ITP Autonomous Cluster Fund (ITP ACF) and the Nazarbayev University Autonomous Educational Center (Nazarbayev University AEC).

On June 14, 2018, a joint decree was signed by the Ministry of Industry and Infrastructural Development (MIID) and the Ministry of Education and Science of the Republic of Kazakhstan (MES) on the "Rules for financing research, scientific, technical and development works in the amount of $1 \%$ of the extraction costs incurred by subsoil user in the previous year." In accordance with this decree, a subsoil user in Kazakhstan receives a legal mechanism to send one percent of their total income over the last year to R\&D. According to the Tax Code of the Republic of Kazakhstan, these funds are sent to Nazarbayev University AEC, ITP ACF, and to the universities accredited in the Ministry of Education and Science of the Republic of Kazakhstan system.

According to the MIID officials, in the period between January 1st and November 112018 , about 1 billion tenge has been attracted from subsoil users to ITP ACF as part of the implementation of the innovation cluster projects and the obligations to finance $R \& D$. During this period, 22 projects were funded for a total of 695 million tenge in the following areas: energy, subsoil use, geological exploration, safety engineering, Industry 4.0, etc. Currently, 11 projects are on the way.

It is important to note that subsoil users will be able to use these funds to organize research laboratories and conduct targeted R\&D involving local and foreign universities, research institutes and scientists. 
Currently, Kazakhstan is offered a wide range of tools for financing innovation through development institutions. One of the most important of those is an incentive tool of innovation grants, that is, state reimbursement of costs to innovators who have passed special selection for the implementation of innovative ideas. This tool has already approved itself among entrepreneurs; the demand for it is growing annually.

Among non-tax measures of state support, technical regulation and the formation of new standards and regulations were mentioned often. It should be noted that in Kazakhstan innovation grants are provided for the following: technological development of industries, technological development of existing enterprises, commercialization of technologies. The technological development of industries in Kazakhstan is governed by the Rules for the provision of innovation grants for the technical development of the industry, and the technological development of enterprises is governed by the Rules for the provision of innovation grants for the technological development of existing enterprises.

The combination of tools used to stimulate the innovative activity of businesses seems important to investigate (table 4).

Table 4. The results of factor analysis of tools to stimulate the innovative activity of businesses

\begin{tabular}{|c|c|c|c|c|}
\hline \multirow[b]{2}{*}{ Stimulation tools } & \multicolumn{4}{|c|}{ Component factor load } \\
\hline & $\begin{array}{c}\text { Vertical } \\
\text { cooperative }\end{array}$ & $\begin{array}{l}\text { Innovatio } \\
\text { n proposal }\end{array}$ & $\begin{array}{c}\text { Foreign } \\
\text { practices }\end{array}$ & $\begin{array}{l}\text { Active state } \\
\text { influence }\end{array}$ \\
\hline Tax relief when investing into $\mathrm{R} \& \mathrm{D}$ & 0.132 & 0.628 & 0.004 & 0.175 \\
\hline $1 \%$ of the total annual income of subsoil users in R\&D & 0.818 & 0.070 & 0.159 & 0.056 \\
\hline “Startup Kazakhstan” Program & 0.211 & 0.162 & 0.698 & 0.047 \\
\hline "Promoting Productive Innovation" project & 0.134 & 0.192 & 0.494 & 0.174 \\
\hline $\begin{array}{l}\text { Technology center development with the involvement and co-financing by } \\
\text { TNCs }\end{array}$ & 0.568 & 0.182 & 0.151 & 0.310 \\
\hline "ITP" Innovation Cluster development & 0.818 & 0.146 & 0.268 & 0.214 \\
\hline Nazarbayev University's Business Campus Astana infrastructure development & 0.829 & 0.248 & 0.148 & 0.236 \\
\hline Technical regulation development, formation of new standards and regulations & 0.159 & 0.280 & -0.250 & 0.705 \\
\hline Promotion and coverage of innovation activity & 0.124 & 0.017 & 0.252 & 0.800 \\
\hline
\end{tabular}

Source: compiled by the authors by the method of principal components

The results of factor analysis have revealed 4 groups of measures corresponding to one of the directions of the policy in innovation performance:

- innovation infrastructure;

- tax relief;

- state financing of innovative projects;

- a "hard" guiding hand (technical regulation, adoption of directives, introduction of standards and norms) or a "soft" one (organization and coordination of interaction).

Support of companies within the framework of the "Promoting Productive Innovation" Project and innovative funding are found between the innovation infrastructure and direct financing. Their relative "proximity" to the infrastructure block, which includes quasi-state funding models, is obvious as priorities of the SPIID-2 and activities of innovation development institutions coincide. 
It is important to note that some incentives for innovation activity at the micro level are combined one way or another with external barriers for its implementation. Thus, manufacturers that felt the influence of tax relief have indicated the difficulty in attracting project investments and the insufficient prevalence of budget co-financing of innovations less often. The first problem is less typical for those who conduct their activities in technology centers and SEZ. Recipients of direct financing (businesses performing innovations), are rather concerned about the insufficient purchases of innovative products by the state.

A clear clustering of government support measures in the areas of policy indicates a connection with significantly different advantages and disadvantages of their application for entities. At the same time, on the one hand, there are obstacles to the complementarity of heterogeneous tools, and on the other hand, the widest possible "coverage" of innovatively active businesses is ensured.

\section{Discussion}

Currently, the number of production entities affected by state stimulation of innovations is very large. Within the analyzed selection, its positive impact has been noted by the majority (60\%) of innovative business heads. Contrary to popular belief, state support is mainly addressed to successful companies rather than outsiders. The maximum "coverage" is peculiar to tax incentives, and by virtue of their specificity, they contribute to a greater extent to the expansion of innovative activity, not to its "start." Only a small part of the measures is focused on a dynamic development of existing and creation of new businesses, and their effectiveness is largely limited by the administration quality. We agree with the study (Jumakulov et al., 2019) that the vast majority of functioning, resource-rich incentive tools is addressed to traditional areas. However, in our opinion, changing business perceptions of technological modernization increases the relevance of developing new, "smart" mechanisms for stimulating innovation, which are proactively adaptable to changing corporate demand for technology.

The low level of innovation is largely associated not only with the difficulties of their implementation, but also with poor business motivation. A significant potential for the impact of competition on innovation remains as well. The share of innovation segment in public procurement is still relatively small (Vazov, 2019), (Kurmanov et al., 2019b). The motivation of entities to innovate is greatly enhanced by tightening technical standards.

The unstable business environment and internal corporate bureaucratization that limit the innovative susceptibility of the business are serious barriers to expanding innovation. Since even positive changes create uncertainty and increase risks, especially for long-term projects, one of the most important tasks is to ensure the stability of management and regulation (Koval, Pukała, 2017). In markets in need of change, appropriate adjustments should be as predictable as possible for the business community. Creating an attractive investment environment would expand the number of innovative businesses. Combining such measures with promoting innovative initiatives focused on demonstration effects and supporting relatively young start-up companies in need of risk sharing is advised as well.

Most companies' choice of import substitution is justified, because they still do not have the necessary potential to promote high-tech products to world markets. However, such mechanisms should not limit competition with foreign players, otherwise the motivation of domestic manufacturers to innovate sharply decreases and conditions for technological borrowing and adaptation worsen. 


\section{Conclusions}

The results of the study of tools to stimulate innovation entrepreneurship indicate that the incentive on the part of the state to carry out innovative activities by entities so far manifests itself in the form of tightening requirements under technical regulations. Only a small part of domestic innovative businesses notes the positive role of public procurement. The contribution of innovation proposal from the Kazakhstan research institutes and universities seems very limited.

In general, the study has confirmed the hypothesis about the positive contribution of public policy to the innovative activities of entities. The current stage of innovation policy performance is characterized, on the one hand, by the creation of a sufficiently diversified toolbox for stimulating innovation entrepreneurship, and, on the other, by the search for new opportunities to activate innovation policies in the context of the fourth industrial revolution.

However, most of the tools to stimulate innovation entrepreneurship at the moment are aimed at successful market players, at creating conditions for the technological modernization of existing industries, and at improving the level of entrepreneurs' business and technological competencies.

According to the study, Kazakhstan needs to increase the participation of universities, research institutes, local executive and legislative authorities in the development of management mechanisms and stimulation of innovation entrepreneurship. It is necessary to create mechanisms able to interest local authorities, development institutions and main participants of the national innovation system in matters of implementing state programs for stimulating entities to innovate.

\section{Reference:}

Caurkubule, Zh. L.; Kenzhin, Zh. B.; Bekniyazova, D.S.; Bayandina, G.D.; Dyussembekova, G. S. (2020). Assessment of competitiveness of regions of the Republic of Kazakhstan, Insights into Regional Development, 2(1): 469-479. http://doi.org/10.9770/IRD.2020.2.1(6)

Chehabeddine, M.; Tvaronavičienè, M. (2020). Securing regional development, Insights into Regional Development 2(1): 430-442. http://doi.org/10.9770/IRD.2020.2.1(3)

Drobnic, J. (2019). The Key Innovations in Career Guidance on Labour Market. Economics. Ecology. Socium, 3(1): 12-22. https://doi.org/10.31520/2616-7107/2019.3.2-2

Howie, P. 2018. Policy Transfer and Diversification in Resource - Dependent Economies: Lessons for Kazakhstan from Alberta, Politics \& Policy, 46 (1): 110-140. https://doi.org/10.1111/polp.12239

Ivanov D.; Kuzyk M.; Simachev Y. 2012. Stimulirovanie innovatsionnoy deyatel'nosti rossiyskikh proizvodstvennykh kompaniy: novye vozmozhnosti i ogranicheniya [Fostering Innovation Performance of Russian Manufacturing Enterprises: New Opportunities and Limitations], Foresight-Russia 6(2): 18-41.

Jumakulov, Z.; Ashirbekov, A.; Sparks, J., Sagintayeva, A. 2019. Internationalizing Research in Kazakhstan Higher Education: A Case Study of Kazakhstan's State Program of Industrial Innovative Development 2015 to 2019, Journal of Studies in International Education 23(2): 234-247. https://doi.org/10.1177/1028315318786445

Kirdasinova K.A., Kurmanov N.A., 2017, Modern mechanisms of innovation management in the development of entrepreneurship of the Republic of Kazakhstan, Interim report, Astana, L.N. Gumilyov ENU. 
ENTREPRENEURSHIP AND SUSTAINABILITY ISSUES

ISSN 2345-0282 (online) http://jssidoi.org/jesi/

2020 Volume 7 Number 4 (June)

http://doi.org/10.9770/jesi.2020.7.4(4)

Kireyeva, A. A.; Mussabalina, D. S.; Tolysbaev, B. S. 2018. Assessment and Identification of the Possibility for Creating IT Clusters in Kazakhstan Regions, Ekonomika regiona [Economy of Region] 14(2): 463-473. http://dx.doi. org/10.17059/2018-2-10

Kolechkina, I., Verchagina, I., Eltsova, E., Petrova, M. 2019. Ecologization of the Development Management of the Mining Regions of Russia. E3S Web of Conferences 134, 02004 (2019) SDEMR-2019, https://doi.org/10.1051/e3sconf/201913402004

Koval V., Polyezhaev Y., \& Bezkhlibna A. 2018. Communicative competences in enhancing of regional competitiveness in the labour market. Baltic Journal of Economic Studies, 4(5): 105-113. https://dx.doi.org/10.30525/2256-0742/2018-4-5-105-113

Koval, V., Pukała, R. (2017). Implementation of regulatory policy in economic activity: development of the institute regulatory impact assessment. Economics. Ecology. Socium, 1(1): 24-32.

Kurmanov N.; Aliev U.; Suleimenov Sh. 2019a. Analysis of the Efficiency of Innovation Management in the Countries of the Eurasian Economic, Polish Journal of Management Studies 19(1): 204-214. http://dx.doi.org/10.17512/pjms.2019.19.1.15

Kurmanov, N.; Petrova, M.; Suleimenova, S. 2019b. Development of a Scientific and Innovative Sphere in Earth Resources Mining Sector of Kazakhstan. IVth International Innovative Mining Symposium E3S Web of Conferences, Vol. 105. Ed. by Tyulenev M.; Zhironkin S.; Khoreshok A.; Vöth S.; Cehlár M.; Nuray D.; Janocko J.; Anyona S.; Tan Y.; Abay A.; Marasová D.; Stefanek P. October 14-16, Kemerovo, Russian Federation, 1-7. https://doi.org/10.1051/e3sconf/201910504045

Kurmanov, N.; Tolysbayev, B.; Aibossynova, D.; Parmanov, N. 2016. Innovative activity of small and medium-sized enterprises in Kazakhstan and factors of its development, Economic Annals-XXI, 158 (3-4 (2)): 57-60. http://dx.doi. org/10.21003/ea.V158-13

Labunska, Sv.; Petrova, M.; Prokopishyna, O. 2017. Asset and cost management for innovation activity, Economic Annals-XXI 165 (5-6): 13-18. https://doi. org/10.21003/ea.V165-03

Lazarova, T., Zhelyazkova, V., Vazov, R. (2015). Innovation leadership as a key concept in entrepreneurship. The 8th International Conference for Entrepreneurship, Innovation and Regional Development. 18th and 19th June 2015 Conference proceedings, University of Sheffield

Lincényi, M.; Čársky, J. (2020). Policy trusts in public policy in the Slovak Republic, Insights into Regional Development, 2(1): 456-468. http://doi.org/10.9770/IRD.2020.2.1(5)

Mikhailov, V., Karasev, V., Mikhailov, G. (2018). The Study of the Main Indicators of the Local Environmental and Economic System "Industrial Enterprise-Environment". E3S Web Conf. Volume 41, 2018. III International Innovative Mining Symposium, https://doi.org/10.1051/e3sconf/20184102015

Mussapirov, K., Djalkibaev, J., Kurenkeyeva, G., Kadirbergenova, A., Petrova, M., Zhakypbek, L. 2019. Business scaling through outsourcing and networking: selected case studieS, Entrepreneurship and Sustainability Issues, 7(2): 1480-1495. http://doi.org/10.9770/jesi.2019.7.2(48)

Naama, K. 2001. "International Movement of Foreign Direct Investments," Economic Thought journal, Bulgarian Academy of Sciences Economic Research Institute, 5: 81-92. https:/www.ceeol.com/search/article-detail? id=221618

Naama, K. 2011. Problems and Solutions for Establishing the Private Sector in Developing Countries. Economic Archive. D. A.Tsenov Academy of Economics- Svishtov. ISSN: 0323-9004, eISSN: 2367-9301, 1: 28-41 https://www.ceeol.com/search/article-detail?id=168228

Odinokova, T. 2019. Tourism cluster as a form of innovation activity. Economics. Ecology. Socium, 3(2), 1-11.

On Technical Regulation. 2004. The Law of the Republic of Kazakhstan, November 9, 2004 No. 603-II. https://online.zakon.kz/Document/?doc_id=1051485

Onyusheva, I. 2017. Analytical and managerial issues of human capital in conditions of global competitiveness: the case of Kazakhstan. Polish Journal of Management Studies 16: 198-209. https://doi.org/10.17512/pims.2017.16.2. 17

Pachura, A. 2015. Innovativeness of an enterprise in the context of technology globalization, Polish Journal of Management Studies 12(1): 143-153. 
ENTREPRENEURSHIP AND SUSTAINABILITY ISSUES

ISSN 2345-0282 (online) http://jssidoi.org/jesi/

2020 Volume 7 Number 4 (June)

http://doi.org/10.9770/jesi.2020.7.4(4)

Petrova, M., Buzko, I., Dyachenko, Y. 2018. Cognitive, Intelligence Technologies and Economical Foundations of Teaching of International Economical Relations and Tourism. 17th International Scientific Conference Engineering for Rural Development, 23.25.05.2018. Jelgava, LATVIA, pp. 1102-1106. https://doi.org/10.22616/ERDev2018.17.N170

Petrova, M., Koval, V., Tepavicharova, M., Zerkal, A., Radchenko, A., Bondarchuk, N. 2020. The interaction between the human resources motivation and the commitment to the organizations. Journal of Security and Sustainability Issues, 9(3): $\underline{\text { http://doi.org/10.9770/jssi.2020.9.3(15) }}$

Petrova, M., Milena Tepavicharova, Lyudmila Dikova. 2019. Factors for development of the educational and professional qualification profile of the human resources in the machine building sector in Bulgaria. Sheregesh, X International Scientific and Practical Conference "Innovations in Mechanical Engineering" (ISPCIME-2019). MATEC Web of Conferences, EDP Sciences, vol.297 (06015), 2019, DOI: https://doi.org/10.1051/matecconf/201929706001

Popova, O., Koval, V., Antonova, L., \& Orel, A. (2019). Corporate social responsibility of agricultural enterprises according to their economic status. Management Theory and Studies for Rural Business and Infrastructure Development, 41(2): 277-289. https://doi.org/10.15544/mts.2019.23

Pukala, R.; Petrova, M. 2019. Application of the AHP Method to Select an Optimal Source of Financing Innovation in the Mining Sector. IVth International Innovative Mining Symposium E3S Web of Conferences, Vol. 105. Ed. by Tyulenev M.; Zhironkin S.; Khoreshok A.; Vöth S.; Cehlár M.; Nuray D.; Janocko J.; Anyona S.; Tan Y.; Abay A.; Marasová D.; Stefanek P. October 14-16, Kemerovo, Russian Federation, 1-6. https://doi.org/10.1051/e3sconf/201910504034

Smirnova, Y. V. 2016. University - industry knowledge transfer in an emerging economy: Evidence from Kazakhstan, Science and Public Policy, 43(5): 702-712. https://doi.org/10.1093/scipol/scv074

SPIID for 2015-2019. (2014). Decree of the President of the Republic of Kazakhstan dated August 1, 2014 No. 874. https://online.zakon.kz/Document/? doc_id=31588425_ (accessed: 08/08/2019).

Tepavicharova, M., Dikova, L., Zahars, V. (2019). Development of a competency model for selection of human resources in the mining and quarrying sector in Bulgaria. IV th International Innovative Mining Symposium E3S Web of Conferences, Vol. 105. Ed. by Tyulenev M.; Zhironkin S.; Khoreshok A.; Vöth S.; Cehlár M.; Nuray D.; Janocko J.; Anyona S.; Tan Y.; Abay A.; Marasová D.; Stefanek P. October 14-16, Kemerovo, Russian Federation, https://doi.org/10.1051/e3sconf/201910504029

Tumalavičius, V., Veikša, I., Načisčionis, J., Zahars, V., \& Draskovic, V. (2017). Issues of the state and society security (part i): ensuring public security in the fight against crime. Journal of Security \& Sustainability Issues, 6(3): 401-418. http://doi.org/10.9770/jssi. 2017.6.3(7)

UNECE. 2012. Innovation Performance Review of Kazakhstan. United Nations Economic Commission for Europe. New York and Gene va: Published by United Nations. https:/www.unece.org/fileadmin/DAM/ceci/publications/icp5.pdf

Vazov R. (2019). Inovative Approaches to Insurance Company Cash Flow Management (contemporary theo retical aspects). Sof ia: VUZF Publishing House "St. Grigorii Bogoslov", ISBN: 978-954-8590-54-9, 136 p.

Vigliarolo, F. (2020). Economic phenomenology: fundamentals, principles and definition, Insights into Regional Development 2(1): 418429. http://doi.org/10.9770/IRD.2020.2.1(2)

Yankovyi, O., Goncharov, Yu., Koval, V., \& Lositska, T. (2019). Optimization of the capital-labor ratio on the basis of production functions in the economic model of production. Naukovyi Visnyk Natsionalnoho Hirnychoho Universytetu, 4, 134-140.

Zahars, V., Stivrenieks, M. (2018). Security, surveillance and re-socialization aspects in Center for drug addicts of Olaine City Prison in Latvia. Journal of Security and Sustainability Issues, 7(4), 643-656. https://doi.org/10.9770/jssi.2018.7.4(3)

Zbierowski R. (2017). The Aspirations of New Technology-Based Firms in CEE and CIS Countries, Foresight and STI Governance 11 (3): 50-60. https://doi. org/10.17323/2500-2597.2017.3.50.60 
Sagyngali SEITZHANOV, PhD Student of Innovation Management, L.N. Gumilyov Eurasian National University, NurSultan, Kazakhstan. Research interests: innovation management, entrepreneurs' innovative activity ORCID ID: https://orcid.org/0000-0002-4900-6310

Nurlan KURMANOV, PhD (Economics), Professor of the Department of Management, L.N. Gumilyov Eurasian National University, Nur-Sultan, Kazakhstan. Research interests: innovation management, entrepreneurship, integration of education, science and business.

ORCID ID: http://orcid.org/0000-0002-3937-6940

Mariana PETROVA, Professor, D.Sc in Physics and Mathematics, Assoc.Prof. St.Cyril and St.Methodius University of VelikoTarnovo, Bulgaria; Professor Economics and Management in Department of Management, ISMA University, Riga, Latvia. Research interests: management of IT processes, project and services, business administration, modern information systems and innovations.

ORCID ID: https://orcid.org/0000-0003-1531-4312

Ulukbek ALIYEV, PhD (Economics), Executive Office of the President of the Republic of Kazakhstan, Nur-Sultan city, "Akorda", Government House, Kazakhstan Research interests: innovation management, entrepreneurship, integration of education, science and business.

https://orcid.org/0000-0002-4904-320X

Nazgul AIDARGALIYEVA, Kazakh Humanitarian Juridical Innovative University, Semey, Kazakhstan. Research interests: higher education, integration of education, science and business

ORCID ID: https://orcid.org/0000-0003-0314-0503

Register for an ORCID ID:

https://orcid.org/register 